\title{
Identification and Localization of a Possible Rhodopsin in the Echinoderms Asterias forbesi (Asteroidea) and Ophioderma brevispinum (Ophiuroidea)
}

\author{
SÖNKE JOHNSEN \\ Department of Biology, University of North Carolina, Chapel Hill, North Carolina 27599
}

\begin{abstract}
Protein extracts of optic cushion tissue from the asteroid Asterias forbesi and arm tissue from the ophiuroid Ophioderma brevispinum were subjected to Western blot analysis. Both tissues contain a membraneassociated protein that reacts with two monoclonal antibodies raised against bovine rhodopsin. This protein migrates slightly behind bovine rhodopsin during sodiumdodecyl-sulfate polyacrylamide gel electrophoresis, suggesting that its molecular weight is slightly larger. Immunohistochemical examination of the optic cushions of $A$. forbesi revealed a substance that reacts with both monoclonal antibodies; moreover, this substance is more abundant in dark-adapted animals than in light-adapted animals. The arms and central disk of $O$. brevispinum were also examined immunohistochemically. The tips of the arm spines contain a substance that reacts with both monoclonal antibodies, and at higher magnification this immunoreactive material is localized to small regions within the stroma of the ossicles. Taken together, the biochemical and immunochemical evidence suggests that the cross-reacting protein is homologous to other known rhodopsins and is serving as a visual pigment in echinoderms.
\end{abstract}

\section{Introduction}

Extraocular photosensitivity in echinoderms is widespread, well documented, and ecologically important (reviewed in Yoshida, 1979; Yoshida et al., 1983), but the functional characteristics, morphology, and distribution of the receptors mediating this sense are poorly understood. At present, the location (subepithelial, dermal,

Received 6 December 1996; accepted 6 May 1997. intra-ossicular, etc.) and ultrastructure (ciliary, rhabdomeric, unspecialized, etc.) of extraocular photoreceptors remain controversial (Cobb and Hendler, 1990; Cobb and Moore, 1986; Millott and Yoshida, 1960; Stubbs, 1981; Yoshida et al., 1983). Among extraocular photoreceptors, those of ophiuroids are of particular interest because portions of the calcitic endoskeleton in ophiuroids transmit, polarize, and possibly focus light (Hendler and Byrne, 1987; Johnsen, 1994). In particular, the crystalline structure of the brachial spines of the ophiuroid Ophioderma brevispinum is ideal for analysis of the polarization of downwelling skylight (Johnsen, 1994). It has becn shown that $O$. brevispinum is scnsitive to polarized light (Johnsen, 1994), and it is hypothesized that this sensitivity is mediated by photoreceptors within the brachial spines.

If the visual pigment in echinoderms were identified, the photoreceptors could be localized using immunohistochemical techniques. The pigment is virtually unknown (reviewed in Yoshida et al., 1983), but several assumptions can be made about it. First, the visual pigment is likely to be a rhodopsin, because all described visual pigments are members of this protein family. Second, it is assumed that essentially the same visual pigment occurs in the photoreceptors of all echinoderms. Third, it is assumed that the optic cushions of asteroids are functionally similar to other metazoan eyes, because a large body of chemical, morphological, and behavioral results suggests that optic cushions are visual organs (Takasu and Yoshida, 1983; reviewed in Yoshida et al., 1983). Given these assumptions, the asteroid optic cushion can be used as a model structure for determining the visual pigment in echinoderms. The optic cushion of $A s$ terias forbesi is particularly suitable as a model because 
it is known that the microvilli of the putative sensory cells within the optic cup of a congener (A. amurensis) become more numerous and increase in size and retinal protein content after long exposure to darkness (Takasu and Yoshida, 1983).

This study describes an immunochemical search for homologues of rhodopsin, first in the optic cushion of the starfish Asterias forbesi and then in the tissues of the brittlestar Ophioderma brevispinum. In both animals, the search revealed a membrane-associated protein, slightly heavier than bovine rhodopsin, that reacts with two monoclonal antibodies raised against bovine rhodopsin. The same antibodies also react with a substance in the optic cups of the optic cushion of $A$. forbesi. In addition, the cross-reaction is stronger in dark-adapted animals than in light-adapted animals. The two monoclonal antibodies also cross-reacted with a substance within the tips of the brachial spines of $O$. brevispinum, suggesting that they contain concentrated amounts of echinoderm rhodopsin. These data all suggest that the purified protein in both animals is homologous to known rhodopsins and that this protein is the visual pigment in echinoderms.

\section{Materials and Methods}

\section{Source and maintenance of animals}

Specimens of $A$. forbesi were oblained from the Marine Biological Laboratory, Woods Hole, Massachusetts. Specimens of $O$. brevispinum were collected from Old Dan Bank, about $2 \mathrm{~km}$ north of the Keys Marine Lab, Layton, Long Key, Florida. Animals were maintained in aquaria in artificial seawater (ASW), salinity $35 \mathrm{ppt}$, on a $12 / 12$ hour light/dark cycle. $O$. brevispinum and $A$. forbesi were kept at $24^{\circ} \mathrm{C}$ and $10^{\circ} \mathrm{C}$ respectively.

\section{Extraction and Western blot analysis}

An adult specimen of $A$. forbesi was dark-adapted for about $20 \mathrm{~h}$. The adaptation was performed because previous studies on several asteroids have shown that the microvilli of the putative sensory cells in the optic cushions increase in number, size, and retinal protein content after long exposure to darkness (Takasu and Yoshida, 1983). Under dim red light, the tips of four arms (containing optic cushions) were removed and immediately frozen in liquid nitrogen. The frozen tissue was pulverized with a mortar and pestle and the powder suspended in $100 \mu 1$ sodium-dodecyl-sulfate (SDS) polyacrylamide gel electrophoresis (PAGE) sample buffer. The solution was incubated at $20^{\circ} \mathrm{C}$ for $5 \mathrm{~min}$ to dissolve all proteins and centrifuged at $16,000 \times g$ for $10 \mathrm{~min}$ to precipitate insoluble material. Because rhodopsins that have been boiled in the presence of SDS irreversibly aggregate, the samples were not boiled before electrophoresis. The supernatant was electrophoresed on an $8 \%$ SDS polyacrylamide gel and transferred to a polyvinyl membrane (Immobilon-P, Millipore Inc.) using the Western transfer process (Harlow and Lane, 1988). The gel lanes were loaded with the maximum amount of protein that could run correctly on the gel apparatus. Nonspecific binding was blocked by incubating the membrane in $1 \mu \mathrm{g} / \mathrm{ml}$ polyvinyl alcohol for $5 \mathrm{~min}$. The membrane was then incubated in a monoclonal antibody raised against bovine rhodopsin (diluted 1:50 in phosphate buffered saline $(140 \mathrm{mM}$ $\mathrm{NaCl}, 3 \mathrm{~m} M \mathrm{KCl}, 8 \mathrm{~m} M \mathrm{Na}_{2} \mathrm{HPO}_{4}, 1.5 \mathrm{~m} M \mathrm{KH}_{2} \mathrm{PO}_{4}$, pH 7.4, referred to hereafter as PBS) containing $0.1 \%$ Tween-20 detergent and $3 \%$ bovine serum albumin (BSA)) for about $20 \mathrm{~h}$ at $20^{\circ} \mathrm{C}$. Fourteen monoclonal antibodies raised against bovine rhodopsin were tested. Their epitope was then investigated using competitive binding assays with various peptide sequences from bovine rhodopsin (Adamus et al., 1991). Figure 1 shows the names and putative epitopes of the antibodies. All 14 antibodies are known to bind with bovine rhodopsin on a Western blot (Hargrave, pers. comm.). Antibodies raised against bovine rhodopsin were chosen because echinoderms are more closely related to chordates than to any other phylum for which rhodopsin antibodies are available. After reaction with the primary antibody, the membrane was washed three times for $5 \mathrm{~min}$ each in PBS, and then incubated for $1 \mathrm{~h}$ at room temperature in goat anti-mouse IgG + IgM conjugated with alkaline phosphatase (Sigma Immunochemicals; diluted 1:5000 in same buffer as primary antibody). The membrane was then washed three times for $20 \mathrm{~min}$ each in PBS and developed according to standard procedures for alkaline phosphatase detection (Harlow and Lane, 1988). The procedure for $O$. brevispinum was identical except that tissue from the arms was used. As a negative control, tissue from the gut of $A$. forbesi was prepared and analyzed in the above manner.

\section{Determination of cellular location of proteins from}

\section{A. forbesi and $\mathrm{O}$. brevispinum}

Tissue from $A$. forbesi or $O$. brevispinum was frozen and pulverized as described above. The powder was suspended in $200 \mu$ l of PBS with $1 \mathrm{~m} M$ phenylmethysulfonyl fluoride and $20 \mu \mathrm{g} / \mathrm{ml}$ leupeptin (referred to hereafter as PBS/PI). The solution was centrifuged for $20 \mathrm{~min}$ at $16,000 \times g$. The supernatant was then centrifuged at $125,000 \times g$ for $1 \mathrm{~h}$ to remove all insoluble material. The supernatant from the high-speed spin was kept and referred to as "C." The pellet from the low-speed spin was resuspended in $200 \mu$ l of PBS/PI with $2 \%$ Triton X-100 and incubated for $30 \mathrm{~min}$. The suspension was then spun 


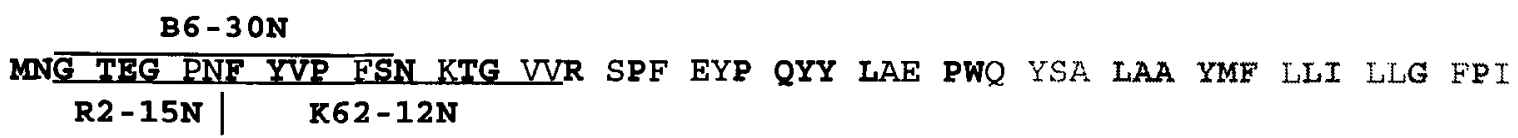

Figure 1. Amino acid sequence of bovine rhodopsin showing the epitopes of the various antibodies used in the study. Light type denotes transmembrane regions that are inaccessible to antibodies in immunohistochemistry. Bold letters indicate amino acid identity among the following 11 chordate rhodopsins: Lampetra japonica, Carassius auratus, Xenopus laevis, Rana pipens, Gallus gallus, Ovis aries, Bos taurus, Mus musculus, Homo sapiens, Cricetulus griseus, and Canis,familiaris. Underlined and overlined regions indicate the epitopes of the antibody listed by the line.

at $16,000 \times g$ for $20 \mathrm{~min}$. The supernatant was kept and referred to as "M." Supernatant C (containing proteins soluble in physiological buffer) and supernatant $M$ (containing proteins insoluble in physiological buffer, but soluble in a mild detergent) were analyzed using Western blot analysis.

\section{Histology of optic cushions from A. forbesi}

The distal tips of the arms of dark-adapted $A$. forbesi were excised and fixed overnight in darkness in $10 \%$ formalin buffered in artificial seawater. The tissue was de- calcified in DeCal (National Diagnostics Inc., Manville, $\mathrm{NJ}$ ), dehydrated in a graded series of ethanols, cleared in Histoclear (National Diagnostics Inc.), and embedded in paraffin. Serial sections $10 \mu \mathrm{m}$ thick were stained with Picro-Ponceau and Weigert iron hematoxylin (Humason, 1979). For additional details concerning histological methods, see Kier (1992). The sections were viewed by both light and confocal microscopy (Zeiss LSM 410 Invert, Thornwood, NY). Light microscopy was used to confirm the staining properties of the various elements, and confocal microscopy was used to increase depth resolution. 
Immunohistochemistry of A. forbesi optic cushions and $\mathrm{O}$. brevispinum arms and central disk

The following procedures were performed in either dim red light or total darkness. The dehydrations, hydrations, permeabilization, washes, and antibody incubations were done on a tissue rotator at $4^{\circ} \mathrm{C}$. Animals were either light- or dark-adapted for $20 \mathrm{~h}$. Tissue was fixed for $2 \mathrm{~h}$ at $20^{\circ} \mathrm{C}$ in $10 \%$ formalin in ASW, dehydrated using a graded series of ethanols $(30 \%, 50 \%, 70 \%$, for $1 \mathrm{~h}$ each), and incubated in $95 \%$ ethanol for $20 \mathrm{~h}$ to extract screening pigments. The tissue was then hydrated, permeabilized in 2\% Triton X-100 in PBS for $20 \mathrm{~h}$, and incubated in either B6-30N or R2-15N (diluted 1:50 in PBS/Tween with 3\% BSA) for 2 days. The tissue was washed in PBS for $30 \mathrm{~min}$ and then incubated in donkey anti-mouse IgG conjugated with $\mathrm{Cy} 5$ or fluorescein (diluted 1:1000) for 1 day. Finally, the tissue was washed for $20 \mathrm{~h}$ in PBS and mounted in $300 \mu \mathrm{l}$ of $n$-propyl-gallate. The stained tissue was observed and optically sectioned using a confocal microscope with accompanying software.

\section{Results}

\section{Biochemical and immunochemical characteristics}

Of the 14 monoclonal antibodies tested, two antibodies, B6-30N and R2-15N, cross-reacted with a protein found in both $A$. forbesi and $O$. brevispinum. None of the 12 other monoclonal antibodies cross-reacted with any proteins found in both animals. Lane BR of Figure 2 shows a Western blot of an extract of bovine rod outer segments incubated in B6-30N. The lanes marked C are Western blots showing the absence of the cross-reacting protein in a solution of proteins soluble in physiological buffer. The lanes marked $M$ are Western blots showing the presence of the cross-reacting protein in a solution of proteins insoluble in a physiological buffer but soluble in Triton X-100. Both lanes $\mathrm{C}$ and $\mathrm{M}$ are replicated for $A$. forbesi and $O$. brevispinum Tissue incubated both in B6$30 \mathrm{~N}$ and in $\mathrm{R} 2-15 \mathrm{~N}$ and the results suggest that the crossreacting protein is membrane-associated. The lanes also show that the mobility of the protein during SDS-PAGE is slightly less than that of bovine rhodopsin. Lane $\mathrm{G}$ shows a Western blot of the gut tissue from $A$. forbes $i$ using the $\mathrm{B} 6-30 \mathrm{~N}$ showing that there is no cross-reaction.

\section{Histology and immunohistochemistry of optic cushion}

The morphology of the optic cushion and optic cups of $A$. forbesi is similar to that observed in Marthasterias glacialis and Asterias amurensis (Smith, 1937; Yoshida, 1966). The optic cushion is an oral, hemispherical expansion of the terminus of the radial nerve cord found directly below the terminal tentacle of the arm (Fig. 3A).
It contains approximately 50 evenly spaccd, pigmentlined, conical optic cups and many isolated pigment spots. The pigment is an intense reddish orange. Figure 3B shows the morphology of a single optic cup. The mouth of the cup is covered by a $0.6-\mu \mathrm{m}$-thick cuticle and a lenticular layer (up to $5 \mu \mathrm{m}$ thick) of optically homogeneous tissue that does not react with any of the stains used. The cup is lined with two types of cells. The first type is more-or-less cuboidal and contains many spherical pigment granules. This cell type is referred to here as a putative pigment cell, because it matches the morphology and distribution of the pigment cells described by Smith (1937) and Yoshida (1966). The second type of cell is elongated and originates from branching fibers with the staining characteristics of nerve tissue; it passes between the putative pigment cells and extends into the lumen of the optic cup. This cell type is referred to here as a putative sensory cell, because it matches the morphology and distribution of the sensory cells described by Smith (1937) and Yoshida (1966). The results of the immunohistochemistry of the optic cushions are shown in Figure 4. The optic cushion docs not react with the secondary antibody (Fig. 4A). The B6-30N antibody cross-reacts with a substance located within the optic cups and the isolated pigment spots of the dark-adapted animals (Fig. 4B). The B6-30N antibody also cross-reacts with a substance located within the optic cups of lightadapted animals, but the cross-reaction is considerably weaker. Figure $4 \mathrm{C}$ shows the strongest cross-reaction observed in a light-adapted animal. No significant staining was observed in the spines or the tube feet. The above results were also obtained using the $\mathrm{R} 2-15 \mathrm{~N}$ antibody (not shown).

\section{Immunohistochemistry of $\mathrm{O}$. brevispinum}

The results of the immunohistochemistry of $O$. brevispinum are shown in Figure 5. The B6-30N antibody cross-reacts consistently with a substance located within the distal tips of the arm spines. No reaction with the secondary antibody is seen in the control (Fig. 5A). The cross-reaction is stronger in dark-adapted animals than light-adapted animals (Fig. 5B, \& C), though the difference is smaller than that observed in $A$. forbesi. The staining is stronger on the lateral spines than on the more oral or aboral spines. There is no consistent change in staining intensity between arm spines on proximal and distal arm segments. No consistent staining was found on any other portion of the arms or on the central disk, though occasional staining was observed at the bases of the arm spines, and a light staining was occasionally observed over the entire surface of the arms. The above results were also obtained using the R2-15N antibody (not shown). 


\section{A. forbesi}

BR

205

140

83

45

33

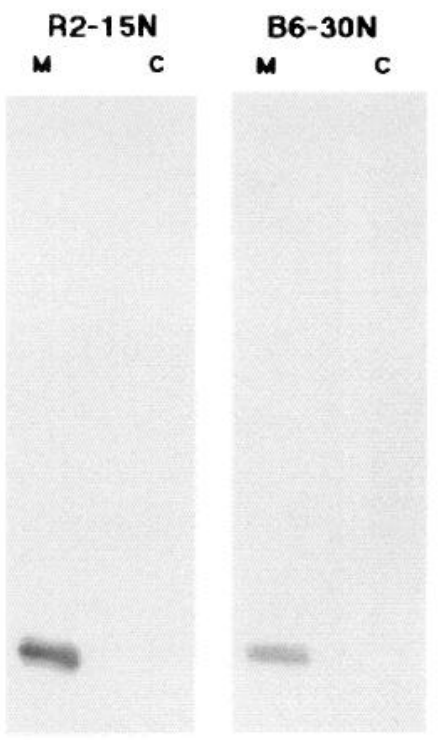

O. brevispinum

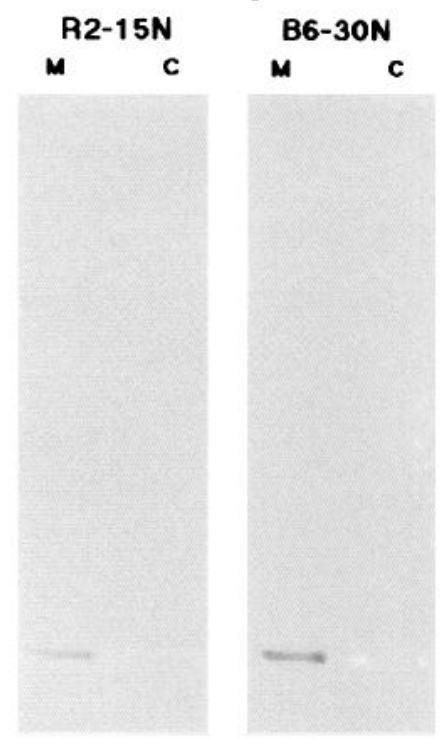

G

Figure 2. Digitized photographs of Western blots. Lane BR: Western blot (using BL-30N) of solution of bovine rod outer segments. The two bands are the monomer and dimer of bovine rhodopsin. Lanes M: Western blot (using B6-30N or R2-15N) of proteins from Asterias forbesi or Ophioderma brevispinum that are insoluble in a physiological buffer but soluble in Triton X-100 detergent. Lanes C: Western blot (using B6-30N or R2-15N) of proteins from A. forbesi or $O$. brevispinum that are soluble in a physiological buffer. Lane G: Western blot (using BL-30N) of gut tissue from A. forbesi.
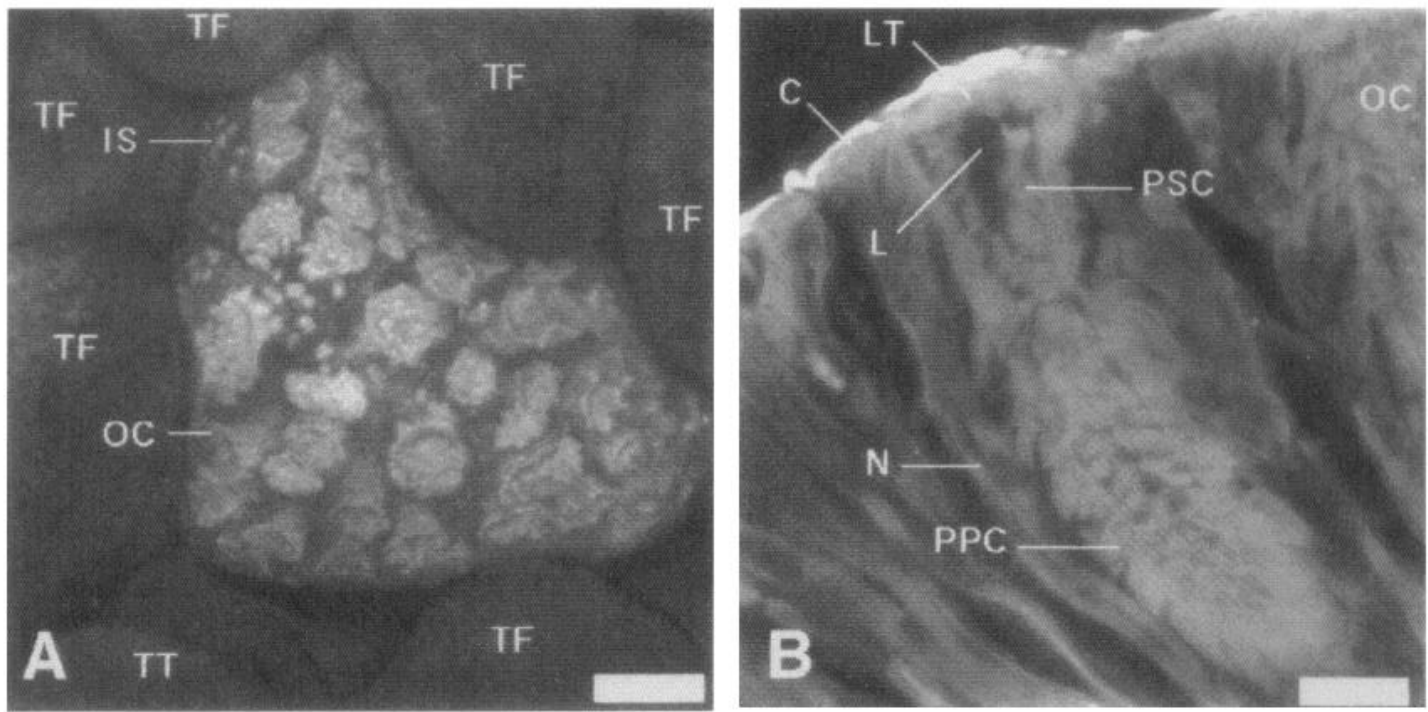

Figure 3. (A) Digitized image of oral view of the arm tips of Asterias forhesi obtained by overlaying 40 confocal images taken at focal depth intervals of $10 \mu \mathrm{m}$. Red pigment is visualized as white. The proximaldistal axis of the arm runs from the upper-right corner to the lower-left corner. Scale bar is $50 \mu \mathrm{m}$. (B) Digitized image of optic cup of $A$. forhesi obtained by overlaying 5 confocal images taken at focal depth intervals of $1 \mu \mathrm{m}$. Images were taken from a $10-\mu \mathrm{m}$ paraffin section stained with Picro-Ponceau and Weigert iron hematoxylin. Scale bar is $10 \mu \mathrm{m}$. OC. optic cup; IS, isolated pigment spot: $C$, cuticle; N. nerve: PPC, putative pigment cell: PSC. putative sensory cell: LT, lenticular thickening: TT, terminal tentacle: TF. tube foot: L. lumen of optic cup. 

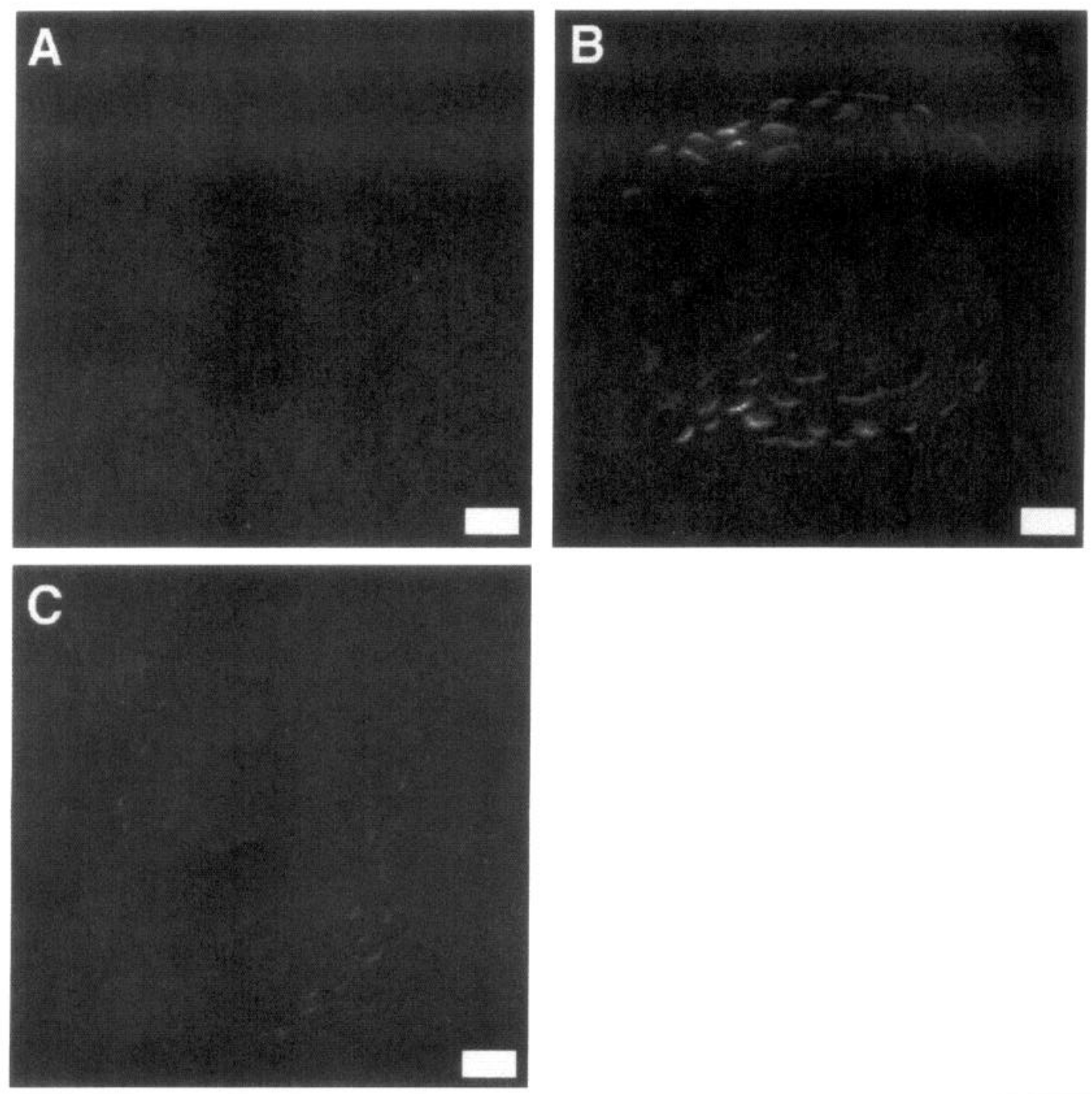

Figure 4. Digitized images of arm tips of Asterias forbesi obtained by overlaying 40 confocal images taken at focal depth intervals of $10 \mu \mathrm{m}$. (A) Control with dark-adapted animal incubated with antibody buffer followed by secondary antibody. (B) Dark-adapted animal incubated with B6-30N antibody followed by secondary antibody. (C) Light-adapted animal incubated with B6-30N antibody followed by secondary antibody. Brightness and contrast in A. B. and C are identical. Scale bar is $50 \mu \mathrm{m}$.

\section{Discussion}

Biochemical and immunochemical evidence relating the visual pigment in echinoderms to chordate rhodopsins

The Western blot analyses and immunohistochemistry provide four lines of evidence that the protein that cross-reacts with the two monoclonal antibodies is homologous to known rhodopsins. First, the mobility of the protein during SDS-PAGE approximates that of bovine rhodopsin. Second, the protein is insoluble in a physiological buffer but soluble in a mild detergent, suggesting that it is membrane-associated. Third, Western blot analysis shows that the purified protein cross-reacts strongly and specifically with two monoclonal antibodies raised against bovine rhodopsin. Finally, both antibodies cross-react with a substance within the optic cups of $A$. forbesi, and this substance is more abundant in darkadapted animals than in light-adapted animals. The morphology of the optic cushions and the optic cups of A. forbesi is similar to that found in other Asterias species that have been studied. Ultrastructural and histofluorescence work on these congeners has demonstrated the presence of organized microvilli and retinal proteins within the lumen of the optic cups (Eakin and Brandenburger, 1979; Penn and Alexander, 1980; Takasu and Yoshida, 1983). In addition, histofluoresence and ultra- 

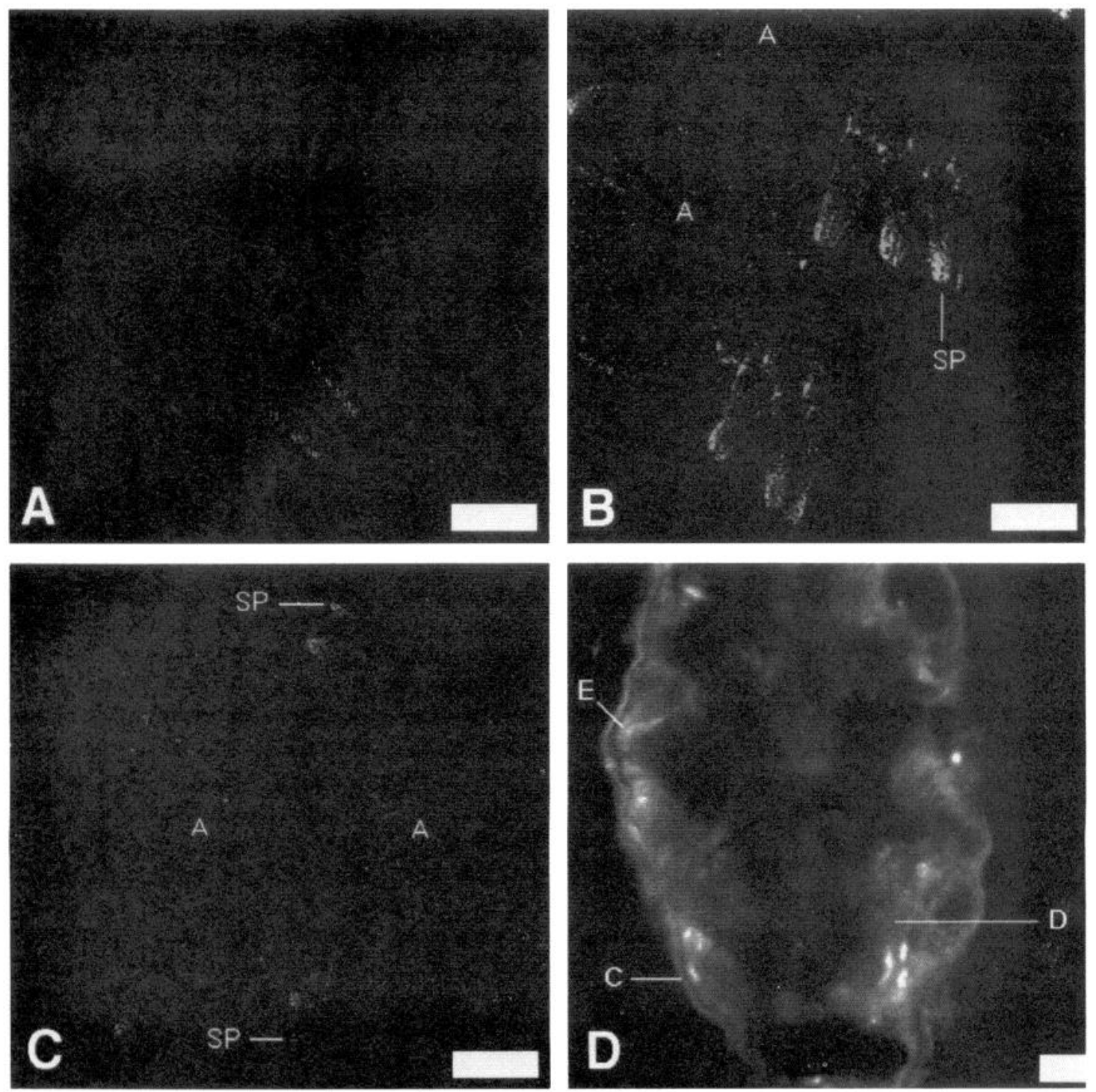

Figure 5. Digitized images of aboral views of 2-3 segments of arms of Ophioderma brevispinum obtained by overlaying 40 confocal images taken at focal depth intervals of $10 \mu \mathrm{m}$. Each segment has two sets of 7 lateral spines each (not all spines visible). (A) Control with dark-adapted animal incubated with antibody buffer followed by secondary antibody. (B) Dark-adapted animal incubated with B6-30N antibody followed by secondary antibody. (C) Light-adapted animal incubated with B6-30N antibody followed by secondary antibody. Brightness and contrast in A, B, and C are identical. Scale bar is $200 \mu \mathrm{m}$. (D) Digitized image of a single longitudinal section of the tip of the central arm spine in B. Scale bar is $10 \mu \mathrm{m}$. SP, arm spine; A. aboral arm plate; $C$, cuticle; E, epidermis; $D$, dermis.

structural investigations have shown that these microvilli and retinal proteins are more abundant in darkadapted animals than in light-adapted animals (Takasu and Yoshida, 1983). Therefore, the substance in the lumen of the optic cups that cross-reacts with the two monoclonal antibodies is probably a rhodopsin and thus, given the specificity of the antibodies in these animals, the cross-reacting protein found in the Western blots.

The possibility remains, however, that the two monoclonal antibodies are reacting specifically with a protein that is unrelated to photoreception. There are two arguments against this possibility. The first is based on the biochemical characteristics of the cross-reacting protein-if the protein is not rhodopsin, it is a membraneassociated protein similar in size to vertebrate rhodopsins. The second involves location-the immunochemistry suggests that the cross-reacting protein is strongly concentrated in the optic cups of $A$. forbes $i$ and more common in dark-adapted than light-adapted animals, suggesting that the protein is involved in echinoderm 
photoreception. The biochemical and immunochemical characteristics considerably limit the number of possible cross-reacting proteins. However, despite the above evidence, protein sequencing or ultrastructural examination of the cross-reacting tissues is required before definite conclusions can be drawn.

\section{Immunohistochemistry of $\mathrm{O}$. brevispinum}

The immunohistochemistry of $O$. brevispinum shows that a substance within the tips of the arm spines crossreacts with monoclonal antibodies raised against bovine rhodopsin. This, in conjunction with the biochemical evidence, the specificity of the antibody, and the immunohistochemistry of the optic cushions of $A$. forbesi, suggests that the substance within the spine tips is a rhodop$\sin$. This result is significant because a variety of ciliary and microvillous structures, presumed sensory in nature, are concentrated at the tips of ophiuroid arm spines (Whitfield and Emson, 1983; Cobb and Moore, 1986). If the photoreceptors of $O$. brevispinum are also concentrated in these regions, then the arm spine tips may be the primary sensory regions of the animal, similar to rhopalia in scyphozoans or asthaetes in polyplacophorans.

This result is also significant because previous work has shown that $O$. brevispinum has polarization sensitivity and that the ossicles of its endoskeleton analyze polarized light (Johnsen, 1994). It is hypothesized that the animal's polarization sensitivity is mediated by differential transmission through its polarizing skeleton. The arm spines are the only ossicles correctly oriented for detecting the plane of polarization of overhead light, so it is appropriate that these ossicles contain photoreceptors. The middle, most lateral, arm spines project horizontally from the lateral surface of the arm, and thus are precisely oriented for detecting overhead polarized light. That they also contain the most rhodopsin (see Results) is, therefore, intriguing.

The possible localization of rhodopsin within the tips of the arm spines does not preclude the presence of rhodopsin in other portions of the animal. It is likely that the cuticle and calcitic endoskeleton limited penetration of the antibodies. In addition, the frequent interfaces between the calcitic endoskcleton and the organic matrix scattered light, thus limiting the ability of the confocal microscope to obtain high-resolution images at a depth of more than $25 \mu \mathrm{m}$ into the ossicles. Electrophysiological evidence has shown that the oral and aboral arm plates of Ophiocoma wendtii and Ophiura ophiura are sensitive to light (Moore and Cobb, 1985; Cobb and Hendler, 1990). In the case of $O$. wendtii, the photoreceptive regions were found to lie quite deep within the ossicles. If these regions exist in $O$. brevispinum, they may be beyond the limit of antibody penetration or coherent imaging by the confocal microscope. Attempts to circumvent these limitations by staining sectioned material were unsuccessful, possibly due to deterioration of the epitope by the embedding procedures (Brandtzaeg, 1982).

In summary, this study identifies a possible visual pigment in the echinoderms. The pigment appears to be a rhodopsin with a molecular weight slightly larger than that of chordate rhodopsins. Immunohistochemistry of the brittlestar $O$. brevispinum shows that this pigment is concentrated within the tips of the arm spines, suggesting that these regions are photoreceptive. The presence of photoreceptors in the spine tips is interesting, both because many sensory cells in ophiuroids are found there and because the polarization properties of the spine ossicles may explain the polarization sensitivity of the animal.

\section{Acknowledgments}

The author thanks Drs. Ann Greig, Ellen Weiss, and Thomas Ingledue for instruction in biochemical, immunochemical, and molecular techniques. The majority of the biochemical work was performed in the laboratory of Dr. Brian Kay, Dept. of Biology, University of North Carolina at Chapel Hill. I thank him for use of lab space, equipment, and reagents. I also thank Drs. William Kier and Ellen Weiss for commenting on early versions of the manuscript. The antibodies against bovine rhodopsin were donated by Dr. Paul Hargrave at the University of Florida at Gainesville. This material is based upon work supported by a National Science Foundation Dissertation Improvement Award (IBN-9411834) awarded to SJ and a National Science Foundation grant (IBN9219495) awarded to Dr. William M. Kier.

\section{Literature Cited}

Adamus, G., S. Z. Zam, A. Arendt, K. Palczewski, J. H. McDowell, and P. A. Hargrave. 1991. Anti-rhodopsin monoclonal antibodies of defined specificity: characterization and application. Vision Res. 31: $17-31$.

Brandtzaeg, P. 1982. Tissue preparation methods for immunocytochemistry. Pp. 1-76 in Techniques in Immunocytochemistry, G. R. Bullock and P. Petrusz, eds. Academic Press, New York.

Cobb, J. L. S., and G. Hendler. 1990. Neurophysiological characterization of the photoreceptor system in a brittlestar, Ophiocoma wendtii. Comp. Biochem. Physiol. 97A: 329-333.

Cobb, J. L.S., and A. Moore. 1986. Comparative studies on receptor structure in the brittlestar Ophiura ophiura. J. Neurocytol 15: 97108.

Eakin, R. M., and J. L. Brandenburger. 1979. Effects of light on ocelli of seastars. Zoomorphology 92: 191-200.

Harlow, E., and D. Lane. 1988. Antibodies: A Laboratory Mantal. Cold Spring Harbor Laboratory, Cold Spring Harbor, NY.

Hendler, G., and M. Byrne. 1987. Fine structure of the dorsal arm plate of Ophiocoma wendti: evidence for a photoreceptor system. Zoomorphology 107: 261-272. 
Humason, G. L. 1979. Animal Tissue Techniques. W. H. Freeman and Co., San Francisco.

Johnsen, S. 1994. Extraocular sensitivity to polarized light in an echinoderm. J. Exp. Biol. 195: 281-291.

Kier, W. M. 1992. Hydrostatic skeletons and muscular hydrostats. Pp. 205-232 in Biomechanics. Structures and Systems: A Practical Approach, A. A. Biewener, ed. IRL Press at Oxford University Press, New York.

Millott, N., and M. Yoshida. 1960. The shadow reaction of Diadema antillarum: the spine response and its relation to the stimulus. $J$. Exp. Biol. 37: 363-375.

Moore, A., and J. L.S. Cobb. 1985. Neurophysiological studies on photic responses in Ophiura ophiura. Comp. Biochem. Physiol. 80A: 11-16.

Penn, P. E., and C. G. Alexander. 1980. Fine structure of the optic cushion in the asteroid Nepanthia belcheri. Mar. Biol. 58: 251-256.

Smith, J. E. 1937. On the nervous system of the starfish Marthasterias glacialis. Philos. Trans. R. Soc. Lond. Ser. B Biol. Sci. 227: 111173.
Stubbs, T. R. 1981. The neurophysiology of photosensitivity in ophiuroids. Pp. 403-408 in Echinoderms: Proceedings of the International Conference. Tampa Bay, J. Lawrence, ed. A. A. Balkema, Rotterdam.

Takasu, N., and M. Yoshida 1983. Photic effects on photosensory microvilli in the seastar Asterias amurensis. Zoomorphology 103: 135148.

Whitfield, P. J., and R. H. Emson. 1983. Presumptive ciliated receptors associated with the fibrillar glands of the spines of the echinoderm. Amphipholis squamata. Cell Tissue Res. 232: 609-624.

Yoshida, M. 1966. Photosensitivity. Pp. 435-464 in Physiology of Echinodermata, R. A. Boolootian, ed. John Wiley and Sons, New York.

Yoshida, M. 1979. Extraocular photoreception. Pp. 581-640 in Handbook of Sensory Physiology, vol. 7/6A, H. Autrum, ed. SpringerVerlag, New York.

Yoshida, M., N. Takasu, and S. Tamotsu. 1983. Photoreception in echinoderms. Pp. 743-772 in Photoreception and Vision in Invertebrates, M. A. Ali, ed. Plenum Press, New York. 